\title{
Multiyear survey targeting disease incidence in US honey bees
}

\author{
Kirsten S. Traynor ${ }^{1}$, Karen Rennich ${ }^{1}$, Eva Forsgren ${ }^{1,2}$, Robyn Rose $^{3}$, Jeffery Pettis ${ }^{4}$, \\ Grace KunKel $^{1}$, Shayne Madella ${ }^{1}$, Jay Evans ${ }^{4}$, Dawn Lopez ${ }^{4}$, Dennis VAnEnGElsdorp ${ }^{1}$ \\ ${ }^{1}$ Department of Entomology, University of Maryland, 4112 Plant Sciences Building, College Park, MD 20742-4454, \\ USA \\ ${ }^{2}$ Department of Ecology, Swedish University of Agricultural Sciences, PO Box 7044, 75007, Uppsala, Sweden \\ ${ }^{3}$ USDA Animal and Plant Health Inspection Service, 4700 River Road, Riverdale, MD 20737, USA \\ ${ }^{4}$ USDA ARS, Building 306, Beltsville Agricultural Research Center-East, Beltsville, MD 20705, USA
}

Received 5 May 2015 - Revised 11 January 2016 - Accepted 26 January 2016

\begin{abstract}
The US National Honey Bee Disease Survey sampled colony pests and diseases from 2009 to 2014. We verified the absence of Tropilaelaps spp., the Asian honey bee (Apis cerana), and slow bee paralysis virus. Endemic health threats were quantified, including Varroa destructor, Nosema spp., and eight honey bee viruses. Varroa loads varied across years, with annual fall peaks; Nosema peaked January to April. Migratory beekeepers had significantly lower Varroa prevalence ( 84.9 vs. $97.0 \%$ ) and loads $(3.65 \pm 0.28$ vs. $5.99 \pm 0.22)$ than stationary operations, while Nosema was more prevalent (59.9 vs. $46.7 \%$ ) in migratory colonies. Since 2010, chronic bee paralysis virus prevalence doubled annually. We detected strong positive relationships between $V$. destructor and Varroa -transmitted viruses, between Nosema and Lake Sinai virus 2, and a positive relationship across several viral pathogens of bees. The results provide a disease baseline to help identify drivers of poor bee health.
\end{abstract}

\section{Apis mellifera / disease survey / pests / parasite / USA}

\section{INTRODUCTION}

Honey bees, Apis mellifera, are the third most economically important agricultural livestock globally after cattle and pork (Tautz 2008). Honey bees are indispensable to the stability of crop production and food security in the USA, contributing $\$ 17$ billion to crop quality and quantity via pollination services (Calderone 2012).

Electronic supplementary material The online version of this article (doi:10.1007/s13592-016-0431-0) contains supplementary material, which is available to authorized users.

Corresponding author: D. vanEngelsdorp, dvane@umd.edu

Manuscript editor: Marina Meixner
Their importance to our agricultural ecosystem was recently acknowledged with a Presidential Memorandum creating a federal strategy to promote the health of honey bees and other pollinators via a Pollinator Health Task Force (Obama 2014). Despite the importance of honey bees, disease baselines that are standard for crop plants as well as other livestock are not currently mandated for bee health. Establishing a baseline of honey bee disease is an important first step toward detecting and mitigating emerging biotic threats (vanEngelsdorp et al. 2014).

In the aftermath of colony collapse disorder (CCD) (vanEngelsdorp et al. 2007), the Animal and Plant Health Inspection Service (APHIS) initiated the National Honey Bee Disease Survey (NHBDS) in the USA and territories to monitor honey bee health and confirm the absence of exotic honey bee pests. This survey is also 
essential to meet import and/or export requirements for international trade outlined by the World Organization for Animal Health (OIE 2014). Finally, this survey allows for the establishment of an epidemiological baseline of disease in honey bee colonies. Even with increased focus on improving honey bee health, winter colony losses have averaged $\sim 30 \%$ over the last 8 years (Lee et al. 2015; Spleen et al. 2013; Steinhauer et al. 2014; vanEngelsdorp et al. 2012; vanEngelsdorp et al. 2008) and annual hive mortality approached $50 \%$ for commercial beekeepers (Lee et al. 2015; Steinhauer et al. 2014).

One of the drivers for the NHBDS is surveillance for three exotic pests and viruses: the introduction of (1) the honey bee mite Tropilaelaps spp., (2) the Asian honey bee Apis cerana, and (3) slow bee paralysis virus (SBPV). These three exotics are serious threats to honey bee health (for details on the risks of these three threats, see the supplementary text $\mathrm{S} 1$ ).

With surveying efforts conducted throughout the majority of the USA, the NHBDS provides a unique opportunity to examine and establish baseline disease levels of common pests, parasites, and viruses. Our random apiary sampling of both migratory and stationary beekeeping operations affords the most systematic and comprehensive view to date of disease levels throughout the year. Previous US sampling efforts focused on determining causes of CCD (vanEngelsdorp et al. 2009) or monitored colony health in the same operation over time (Runckel et al. 2011; vanEngelsdorp et al. 2013b) and may have biased sampling toward worst-case scenarios. Therefore, in addition to the exotic threats driving this survey, we measured incidence and levels of Varroa destructor, Nosema spp., and a diverse set of honey bee viruses.

\subsection{Viruses}

Most viruses infecting honey bees are positivesense single-stranded RNA viruses belonging to the Picornavirales order. Approximately 24 viruses have been identified in honey bees to date, but several of these viruses are closely related and arguably are members of single-species complexes, reducing the number of distinct viruses to approximately 16-18 (Bailey and Ball 1991; de Miranda et al. 2013; Ribière et al. 2008). Honey bee viruses generally persist at low levels in honey bee populations without causing overt symptoms. However, under certain conditions, they can become pathogenic and widespread, leading to colony mortality. For example, covert honey bee virus infections often become symptomatic when their honey bee hosts face stress (DeGrandi-Hoffman et al. 2010; Di Prisco et al. 2013; Di Prisco et al. 2011). Increasing virus transmission and escalating colony health problems have been closely linked to Varroa-mediated virus transmission (Le Conte et al. 2010; Locke et al. 2014; vanEngelsdorp et al. 2013b). Along with the targeted species, SBPV, our virus screening focused on two highly prevalent species (deformed wing virus (DWV) and black queen cell virus (BQCV)), three common dicistroviruses (ABPV, KBV, and IAPV), and two distantly related and under-surveyed viruses (CBPV and LSV-2), see Table I.

Varroa acts as a vector of viruses, propelling an increased need to monitor virus prevalence. Before Varroa, researchers could rarely attribute honey bee health problems to virus activity, a strong indication of a sustainable balance achieved in the coevolution of viruses and honey bees. Varroa provided a new infection route - the direct injection of viruses into the hemolymph — opening a new niche for viruses to replicate and develop greater virulence with unpredictable consequences (Genersch and Aubert 2010) (for more details on why these specific honey bee viruses are of interest, see supplementary text S2).

While time-consuming and costly, long-term monitoring efforts such as the NHBDS provide crucial information on the continued absence of exotic pests, provide baseline disease levels, and permit detection of potentially escalating problems.

\section{MATERIALS AND METHODS}

\subsection{Scope of survey}

This effort was the result of 6 years of survey, with the individual samples collected between August 2009 and the end of November 2014, with each survey 
denoted by the letters A-F (Table I). Representative samples from states were taken throughout the beekeeping season, but individual apiaries selected by apiary inspectors were sampled only once per year and not tracked over time. The number of states and territories participating in each survey varied from a low of 3 (survey A in 2009-2010) to a high of 34 (survey C in 2011-2012). While most diagnostic efforts were the same across all survey years, we replaced a two-step RT-PCR protocol with a one-step RT-PCR protocol to minimize the risk of cross-contamination (Table I, Suppl. Table S1).

\subsection{Sample sizes}

Eight colonies of average strength (as determined by frames of bees) per apiary were sampled in accordance with the APHIS National Honey Bee Disease Survey protocol from apiaries that contained a minimum of ten colonies (Rose et al. 2014). In the apiary from a selected operation, three different composite samples were collected from eight colonies: (a) adult worker bees collected in a live-bee shipping box for the analysis of viruses; (b) adult worker bees collected in alcohol to detect and quantify Varroa loads, Nosema spores, and A. cerana; and (c) a sample of brood-frame debris to detect Tropilaelaps. In the early years of the survey (surveys A, B, and C), the survey protocol included sampling from 25 apiaries in each state, with twice as many taken in CA due to the large influx of colonies for almond pollination. In recent surveys (surveys D, E, and F), 24 apiaries were sampled per participating state, except in CA where 48 samples were collected.

\subsection{Survey history}

The first survey effort (A) was initiated in 2009 as a pilot study in three states to field test the survey equipment kits, sampling protocols, diagnostic testing, coordination with state apiarists, and shipping feasibility. The pilot was conducted in CA, FL, and $\mathrm{HI}$ due to higher risks to bee health from exotic pests entering the USA, warmer climate, long growing seasons, and movement of honey bee colonies into CA during almond pollination.

The survey expanded to 13 states in 2010 (Table II, survey B) that included key beekeeping states and a wide geographic distribution of the USA. Attempts were made to include a distribution of states that 


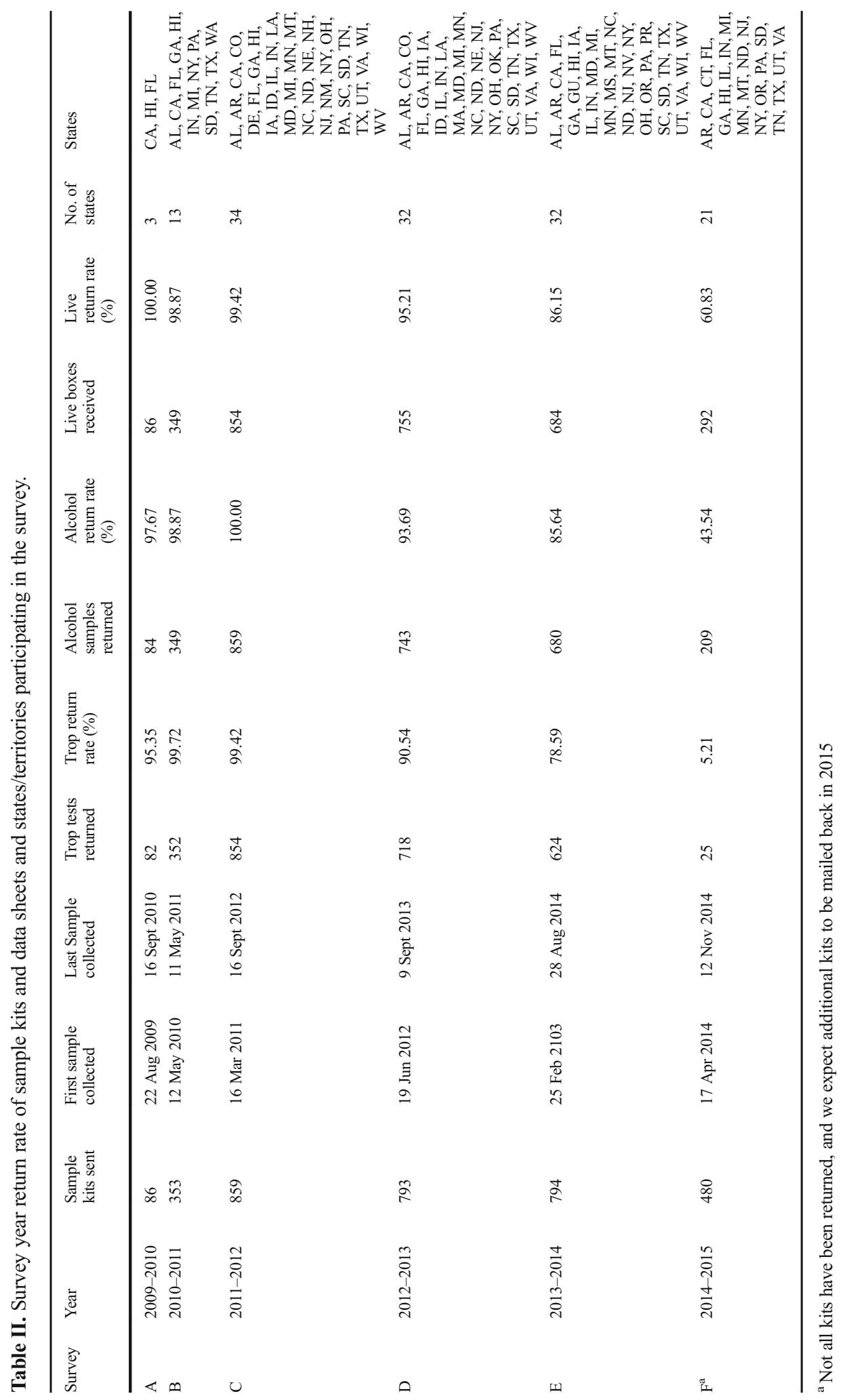


represented queen production, honey production, and those that had both stationary and migratory practices. From 2011 to 2013, surveys C-F 34, 32, 32, and 21 states participated, respectively (see Table II).

\subsection{Selection of apiaries to sample}

Each participating state was sectioned into four quadrants with equal numbers of apiaries randomly chosen within a quadrant. When possible, ten queen producers were sampled. Of the remaining sampled apiaries, one half were from migratory operations (move out of state and return prior to sampling) and one half were from stationary operations (do not move hives across state lines), both commercial- and smallscale operations. Additional apiaries occurring near ports or other areas that could be considered high risk were also sampled.

\subsection{Sample types}

Three distinct collection methods were used by state apiary specialists to sample each apiary. Samples were immediately mailed to the USDA/ARS Bee Research Laboratory in Beltsville, MD (BRL) and then subsequently analyzed by the University of Maryland (UMD) or Agricultural Research Service (ARS). The first sample, used for molecular viral analysis, was a collection of live adult bees composed of one-fourth cup of bees ( $\sim 150$ bees) that were shaken off brood frames from each of the eight sampled colonies ( 1200 bees total). The live bees were deposited in a live-bee shipping box containing a water source and hard sugar candy (fondant). Upon receipt, this box was immediately frozen at $-80{ }^{\circ} \mathrm{C}$ until molecular testing could be performed as outlined below. Percent survivability was tracked for all live bee shipments. This method has proven to be robust and a suitable alternative to shipping bees on dry ice. In some survey years, a very small number of live bee samples (mean 2.5 samples, range 0-7 per survey) were delayed in shipment and degraded badly enough that no molecular data could be retrieved from the samples.

The second sample of bees, consisting of one-fourth cup of bees from each of the eight sampled colonies, originated from the same brood frames as the live bee sample. These bees were put into $500 \mathrm{~mL}$ of $70 \%$ ethanol for preservation. This sample was analyzed for the following: Nosema spp. spores per adult bee (Cantwell 1970), V. destructor infestation per 100 bees
(DeJong et al. 1982; Lee et al. 2010), and Acarapis woodi (survey years A and B only) after (Shimanuki and Knox 2000). Since honey bee tracheal mites (A. woodi) were not detected in samples in 2009 nor in 2010, samples were not subsequently analyzed for this mite. Each sample was screened visually for A. cerana, as the much smaller worker size is readily discernable. These results were further confirmed by a diagnostic genetic test for $A$. cerana, described below.

The third sample was taken from anything dislodged from "bumping" sampled brood frames over a collection pan as described in Pettis et al. (2013b). This sample, also preserved in $70 \%$ ethanol, was analyzed for the presence of the Tropilaelaps and included other mites, beetles, and hive debris filtered from bumping the brood frame.

As in any survey, not all respondents participate. The return rate is calculated as the percentage of samples received (any portion of the requested samples returned) from the total number of kits sent out. The transit time is calculated as the amount of time that the live-bee kits were en route from the day that they were sampled until they were received and frozen. The survival rate is the percentage of bees still alive in the live-bee box at the time that the shipment was received at the diagnostic lab. Dead bees were discarded and only live bees frozen for molecular analysis.

\subsection{Molecular diagnostics}

\subsection{1. $R N A$ extraction and $c D N A$ synthesis}

Survey years $A, B, C$, and $D$ Bulk samples of 50 adult bees (stored at $-80^{\circ} \mathrm{C}$ ) were placed in a disposable extraction bag with $500 \mu \mathrm{L}$ guanidine thiocyanate lysis (GITC) buffer per bee, $25 \mathrm{~mL}$ total, and RNA was extracted using the acid phenol protocol (see Sect. 4.3.3 in (Evans et al. 2013)). Following RNA extraction, DNA was removed from the samples using DNase I incubation at $37{ }^{\circ} \mathrm{C}$ for $1 \mathrm{~h}$ followed by $10 \mathrm{~min}$ at $75^{\circ} \mathrm{C}$. First-strand complementary DNA (cDNA) was generated from approximately $2 \mu \mathrm{g}$ total RNA using a master mix containing $50 \mathrm{U}$ Superscript II (Invitrogen), random primer set (7-mer at 10$\mathrm{mM}$ concentration), 2 nmol dNTP mix, 2 nmol polydT-18, and $0.1 \mathrm{nmol}$ polydT (12-18). The cDNA synthesis was carried out at $42{ }^{\circ} \mathrm{C}$ for $50 \mathrm{~min}$ followed by $15 \mathrm{~min}$ at $70{ }^{\circ} \mathrm{C}$ (Evans 2006). 
Survey years $E$ and $F$ Bulk samples of 50 adult bees were placed in a disposable extraction bag with $200 \mu \mathrm{L}$ of GITC buffer per bee (see Sect. 4.2 in (Evans et al. 2013)), $10 \mathrm{~mL}$ total, and flash frozen with liquid nitrogen and homogenized using a pestle. One hundred microliters of the grinded tissue was mixed with $600 \mu \mathrm{L}$ RLT buffer with $\beta$-mercaptoethanol (Qiagen). For each bulk sample, total RNA was extracted from $100 \mu \mathrm{L}$ of the crude extract using the RNEasy ${ }^{\mathrm{TM}}$ Mini Qiacube kit and a Qiacube ${ }^{\mathrm{TM}}$ extraction robot for automated purification (Locke et al. 2012). The quantity of extracted RNA was measured using the NanoDrop 8000 in nanogram per microliter and subsequently diluted to $20 \mathrm{ng} / \mu \mathrm{L}$. No separate cDNA synthesis was performed on the 2013 samples. The extracted RNA was stored at $-80{ }^{\circ} \mathrm{C}$ until processed.

\subsubsection{RT-qPCR assays}

Survey years $A, B C$, and $D$ All composite bee samples were screened for seven honey bee viruses and the microsporidia Nosema ceranae and Nosema apis (Table I, Suppl. Table S1) via real-time PCR using Bio-Rad SsoFast ${ }^{\mathrm{TM}} \mathrm{SYBR}^{\circledR}$ Green Supermix, 96-well optical PCR plates, and a Bio-Rad CFX Connect ${ }^{\text {TM }}$ thermal cycler. The single-tube PCR assays were performed in $20-\mu \mathrm{L}$ volumes containing $500 \mathrm{ng}$ cDNA and $250 \mathrm{nM}$ of each primer. Positive controls (purified PCR product) and non-template controls (nuclease-free $\mathrm{H}_{2} \mathrm{O}$ ) were included in each run. The following cycling conditions were used: enzyme activation at $95{ }^{\circ} \mathrm{C}$ for $30 \mathrm{~s}$, followed by 40 cycles of denaturation at $95^{\circ} \mathrm{C}$ for $5 \mathrm{~s}$, and annealing/extension $60{ }^{\circ} \mathrm{C}$ for $5 \mathrm{~s}$. To check for specificity, the amplification reaction was followed by a melting curve analysis (reading the fluorescence at $0.5{ }^{\circ} \mathrm{C}$ increments from 60 to $95{ }^{\circ} \mathrm{C}$ to capture the dissociation point, a diagnostic for amplicon fidelity). Quantification by qRT-PCR of the honey bee transcript for actin provided a measure of RNA quality and quantity, allowing for the calculation of relative target loads.

\section{Survey years $E$ and $F$ In these 2 years, BQCV was} replaced by LSV-2 (Runckel et al. 2011). Each sample was also assayed for mRNA levels of the internal reference gene Rp49 rather than the more variable actin. The amount of each virus and Rp49 in the samples was determined by real-time RT-qPCR using Bio-Rad iTaq $^{\mathrm{TM}}$ Universal SYBR ${ }^{\mathbb{B}}$ Green One-Step Kit, 96-well optical qPCR plates, and the Bio-Rad CFX Connect ${ }^{\mathrm{TM}}$ thermal cycler. The single-tube RT-qPCR assays were performed in $10-\mu \mathrm{L}$ volumes, containing $60 \mathrm{ng} \mathrm{RNA}$, $0.2 \mu \mathrm{L}$ (quant) of each primer, and $0.4 \mu \mathrm{L}$ (units) iScript. Three positive controls and one non-template control (nuclease-free $\mathrm{H}_{2} \mathrm{O}$ ) were included for each assay. Recombinant DNA templates for each target were used as positive controls in every run and covered 6 orders of magnitude difference in concentration. These were used to establish the calibration curves for quantification of the target amounts. All real-time reactions (standards, unknown samples, and controls) were performed in neighboring wells on each sample plate. The following cycling conditions were used: $10 \mathrm{~min}$ at $50{ }^{\circ} \mathrm{C}$ for cDNA synthesis plus $5 \mathrm{~min}$ at $95{ }^{\circ} \mathrm{C}$ for reverse transcription inactivation and Taq polymerase activation, followed by 35 cycles of $10 \mathrm{~s}$ at $95{ }^{\circ} \mathrm{C}$ denaturation and $30 \mathrm{~s}$ at $58{ }^{\circ} \mathrm{C}$ for extension and data collection. The amplification reaction was followed by melting curve analysis to determine the specificity of the amplification products, by incubating for $60 \mathrm{~s}$ at $95{ }^{\circ} \mathrm{C}$ and $60 \mathrm{~s}$ at $55^{\circ} \mathrm{C}$ and then reading the fluorescence at $0.5^{\circ} \mathrm{C}$ increments from 55 to $95{ }^{\circ} \mathrm{C}$.

\subsubsection{Generation and analysis of quantitative RT-PCR data (survey years $E$ and $F$ )}

The RT-qPCR data were first screened for the presence of specific target PCR product, as determined by the melting curve analyses. The $\mathrm{Cq}$ values of all confirmed target amplifications were calculated by the BioRad CFX Manager ${ }^{\mathrm{TM}}$ Software version 2.1 following a reaction baseline subtraction using the Global Minimum Trend option and with the fluorescence threshold set uniformly at 0.05 for all plates. All Cq values coincided with the logarithm phase of the amplifications. For each target RNA, the external dilution standards included in every RT-qPCR run were pooled into a single linear regression analysis of $\mathrm{Cq}$ value onto $\log _{10}$ [template]. These regression equations were then used to estimate the absolute amounts of virus and Rp49 RNA in each reaction and to calculate the amplification efficiencies $(E)$ of the different assays:

$E_{\text {assay }}=10^{-1 / \text { slope }}$ (Bustin et al. 2009). For each sample, the amount of virus was normalized to the average Rp49 levels effectively using Rp49 as a molecular marker for the quantity and quality of the RNA sample. 
These values were then multiplied by the different experimental dilution factors to arrive at the estimated number of virus genome equivalents per bee.

\subsection{Diagnostic genetic screen for $A$. cerana (survey years A through D)}

Samples were amplified in $30-\mu \mathrm{L}$ reactions containing $1 \mu \mathrm{L}$ of cDNA, $1 \mathrm{U}$ Taq DNA polymerase and $1 \times$ proscribed buffer (Roche, Indianapolis, IN), $0.4 \mu \mathrm{M}$ each of primers that amplified the transcript for ribosomal protein L17 (Rp17both.F, Rp17mel448.R), and $2 \mathrm{mM} \mathrm{dNTP}$. The following cycling parameters were used: $94{ }^{\circ} \mathrm{C}$ for $2 \mathrm{~min}$, followed by 30 cycles of $94^{\circ} \mathrm{C}$ for $1 \mathrm{~min}, 52^{\circ} \mathrm{C}$ for $45 \mathrm{~s}, 72{ }^{\circ} \mathrm{C}$ for $45 \mathrm{~s}$, ending with an final extension at $72{ }^{\circ} \mathrm{C}$ for 5 min All plates contained a no-template control, as well as A. cerana and A. mellifera DNA-positive controls.

PCR products were subjected to digestion with AluI (New England Biolabs, Ipswich, MA) in $20-\mu \mathrm{L}$ reactions containing $5-\mu \mathrm{L}$ PCR product, $1 \mathrm{U}$ AluI, and $1 \times$ buffer NEBuffer4. Reactions were incubated for $1 \mathrm{~h}$ at $37^{\circ} \mathrm{C}$ and then heat inactivated for $20 \mathrm{~min}$ at $65^{\circ} \mathrm{C}$. The digests were separated on a $1.7 \%$ TAE gel after which visual inspection of cut/uncut PCR products indicated the presence of each species, since this enzyme specifically cuts the product generated for A. cerana . Control digestions of A. cerana and A. mellifera digestions were run on each plate for controls.

\subsection{Statistics}

Statistical analysis was conducted using JMP ${ }^{\circledR}$ 11.0.0 (SAS, Cary, NC). Transit time and live bee survival were analyzed using multivariate pairwise correlations. Comparisons across months, years, or interactions were analyzed with multifactorial ANOVA for transit times, live bee survival, Varroa infestation, and Nosema spore counts. Varroa, Nosema, and viral prevalence (absence vs presence) was calculated, as were $95 \%$ confidence intervals (CIs), from all samples taken from the same apiary. Statistical analysis of virus prevalence included the initial pilot survey year $(N=17)$ when compared across years, but these samples were excluded when analyzed by month due to limited sampling times. When the number of diseased apiaries was $\geq 10$ and the number of inspected apiaries-diseased apiaries was also $\geq 10$, a normal distribution (i.e., $Z$ alpha $=1.96)$ was assumed as an appropriate approximation of a binomial distribution (Koepsell and Weiss 2003). In cases where these conditions were not met, a binomial distribution (see vanEngelsdorp et al. 2013a, b for details) was used to calculate the $95 \%$ CI (http://statpages.org/confint.html). Relationships between viruses were explored by calculating odds ratios according to standard methods (vanEngelsdorp et al. 2013a). Differences in prevalence levels over time or between groups were tested using chi-square tests or by comparing $95 \% \mathrm{CI}$; when $95 \% \mathrm{CI}$ of two populations did not overlap, we considered the populations different. Standard $t$ tests were implemented to compare Nosema and Varroa infestation levels between the primary income source of a bee business (queen production, honey, pollination, nuc production, or hobby) with all other samples not engaged in that primary income stream.

\section{RESULTS}

\subsection{Return rate}

For survey efforts A-D, when apiary inspectors were paid for their collection time, return rates remained at $95 \%$ or above for live bee boxes and $90 \%$ or above for alcohol and Tropilaelaps samples. Participation rates dropped slightly for survey effort $\mathrm{E}$ but remained above $85 \%$ for live bees and alcohol samples. As expected, not all samples for survey year $\mathrm{F}$ were received before the end of 2014, and so, the response rate currently appears low, but it is expected to increase in 2015 as in prior years (Table II).

\subsection{Live bee survivorship rate during transit}

For all years, there is a significant negative correlation between transit time and percentage of bee viability in the live bee boxes. This varies from a low of $r=-0.48$ in 2014 to a high of $r=-0.74$ in 2009 . When analyzed by month, transit time and the percent received alive were negatively correlated for all months except March. Transit time varied significantly by month $\left(F_{11,2894}=3.88, P<0.0001\right)$. Shipments had the greatest transit time in May (mean $=5.33$ days $\pm 0.30)$ and the shortest transit time in October (mean $=3.40$ days \pm 0.20 ). Bee survival during 
shipment also varied significantly by month $\left(F_{11,2823}=7.08, P<0.0001\right)$, with lowest survival rates in December during the holiday shipping season $($ mean $=69.9 \% \pm 3.62 \%$ ) and highest in June $($ mean $=91.6 \% \pm 1.36 \%)$.

\subsection{Varroa and Nosema by year}

Throughout survey efforts, alcohol samples were processed for Varroa and Nosema spore loads $(N=2901)$. All together, $91.7 \%$ of samples were positive for mites, while $52.5 \%$ were positive for Nosema spores. Varroa prevalence $\left(\chi 5^{2}=23.55, P=0.0003\right)$ and load $\left(F_{5,2895}=15.31, P<0.0001\right)$ differed significantly by sampling year (Table III). Nosema prevalence $\left(\chi_{5}{ }^{2}=14.31, P=0.0138\right)$ and Nosema load $\left(F_{5,2868}=2.87, P=0.0138\right)$ also differed significantly by year (Table III).

\subsection{Varroa and Nosema by month}

Varroa infestations demonstrate seasonal cycles that typically peak in late summer and early fall. Sample mite loads differed significantly by month (Figure 1, $F_{11,2883}=44.19, P<0.0001$ ), with September-November having mean mite loads above 5.5 mites. From July through November, mean mite levels were above the treatment threshold of three mites per 100 bees (Genersch et al. 2010; Giacobino et al. 2015). However, it is only from August-November that we find more than $50 \%$ of samples above the treatment threshold (three mites per 100 bees) with a max infestation rate of 64 mites per 100 bees detected in September 2011.

Nosema loads differed significantly by month (Figure 2, $F_{11,2883}=26.61, P<0.0001$ ), with only the month of April having mean Nosema loads above the treatment threshold of 1.0 million spores per bee (Mussen, personal communication), significantly higher than any other sampling time. The highest spore count detected during the survey was 13.95 million spores per bee in April 2011.

\subsection{Nosema species}

In addition to testing Nosema prevalence, we tested Nosema species using molecular 




Figure 1. Mean mite load per 100 bees by month. Error bars depict $95 \%$ confidence intervals (CIs), and different letters indicate significant differences. Orange line represents three-mite treatment threshold.

assays from 2009 to 2013. The prevalence of $N$. ceranae varied significantly by sampling year (Table IV, $\chi_{4}{ }^{2}=258.89, n=1773$, $P<0.0001$, see Suppl. Figure S1), increasing from $29.41 \%$ in 2009 to $88.42 \%$ in 2013.
N. apis prevalence also varied significantly by year (Table IV, $\chi_{4}^{2}=13.23, n=1772$, $P=0.0102$, see Figure $\mathrm{S} 1$ ), appearing in $1.0-1.5 \%$ of samples in 2012 and 2013, while undetected in other years.

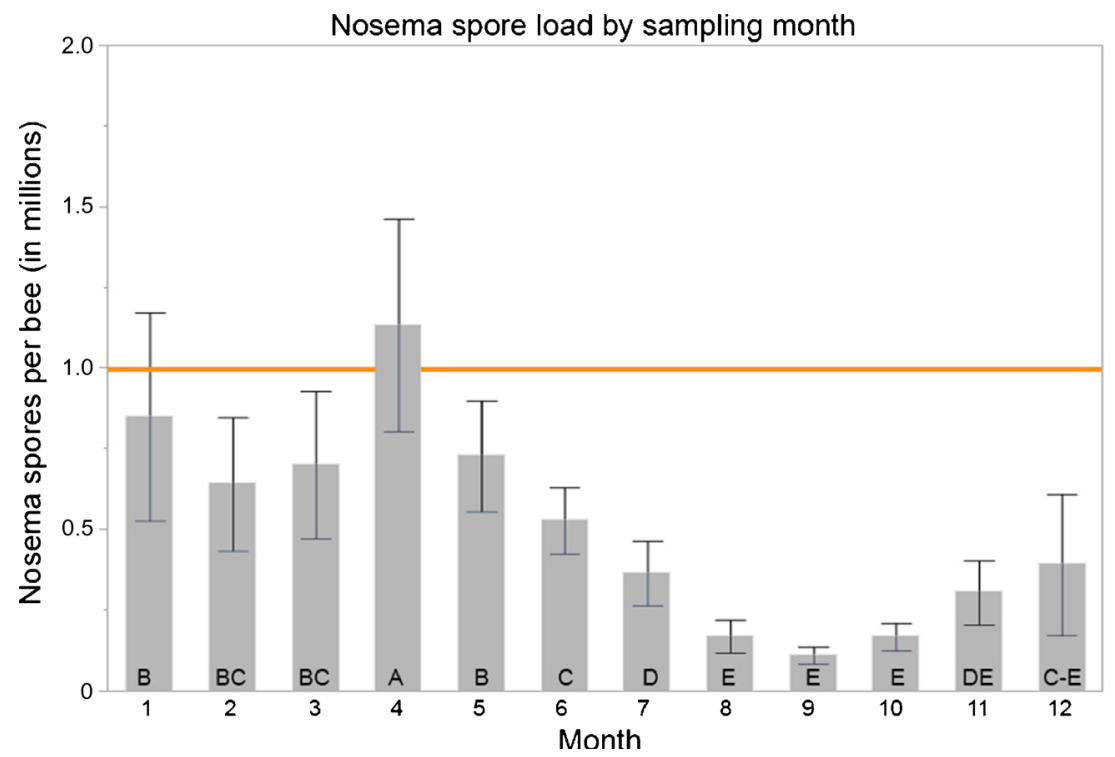

Figure 2. Mean Nosema load per bee by month. Error bars depict $95 \%$ CI, different letters indicate significant differences. Orange line represents 1 million spores per bee threshold. 


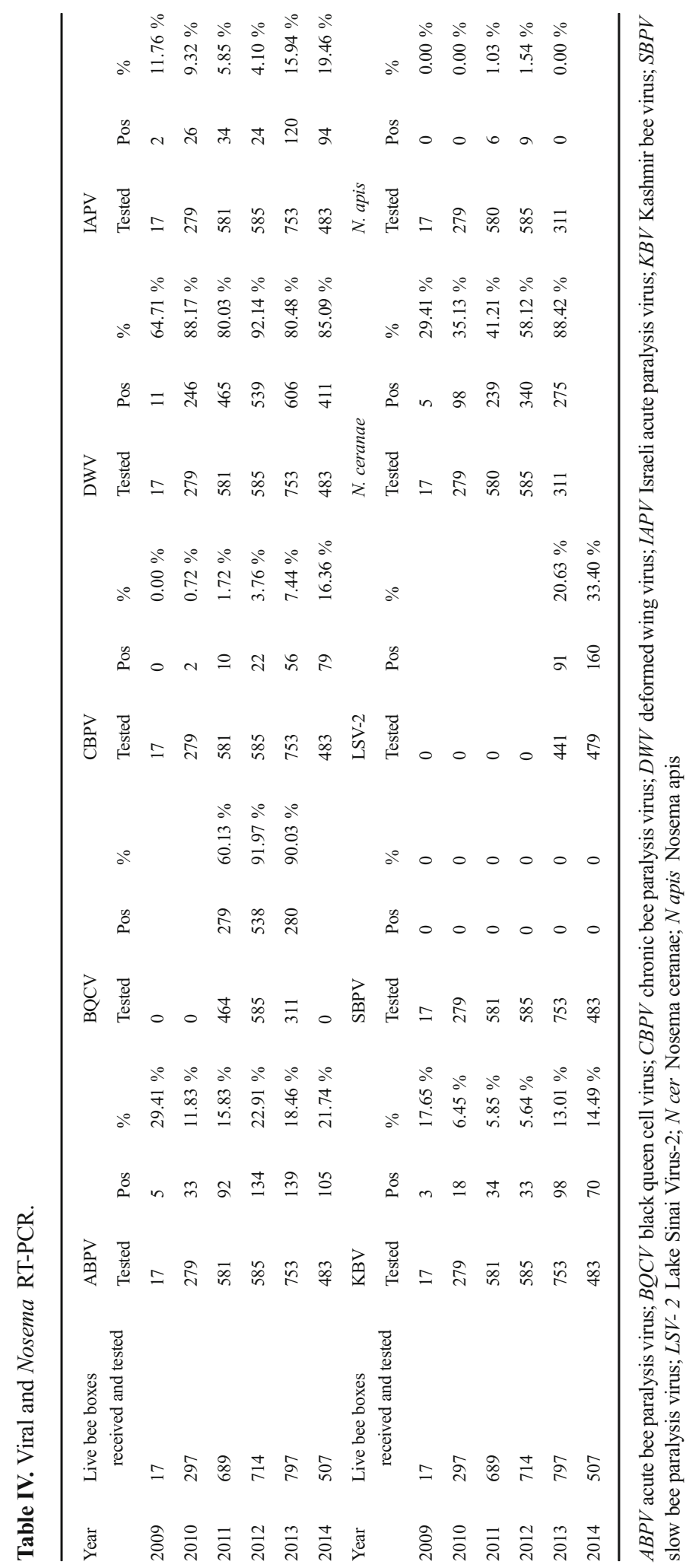




\subsection{Migratory vs. stationary beekeepers}

For all survey years, a total of 1294 respondents classified their operations as either stationary or migratory. Of these respondents, $37.6 \%$ of the sampled apiaries were migratory (see Table V). A breakdown of the disease loads in migratory vs. stationary operations is given in Table VI. Notably, across all samples, migratory beekeepers had significantly lower mite prevalence than stationary operations (84.9 vs. $97.0 \%$ ) and lower mean mite loads (Figure 3, $3.65 \pm 0.28$ vs. $5.99 \pm 0.22$ Varroa per 100 bees). Nosema showed the inverse relationship and was significantly more prevalent (59.9 vs. $46.7 \%$ ) and abundant (Figure $4,0.44 \pm 0.04$ vs. $0.24 \pm 0.03$ million spores per bee) in migratory operations.

\subsection{Primary income stream of bee operation}

Over all years, 2353 operations indicated the primary type of income stream of their bee operation (honey, queen, nuc, pollination, or hobbyist). The majority $(n=1826)$ indicated that they had one principal source of income, while 494 operations indicated two business types (i.e., honey production and pollination), and 34 indicated three (see Table VII). Queen producers had lower Varroa loads compared to operations that did not produce queens for income (Suppl. Figure S2, $3.78 \pm 0.33$ vs. $4.83 \pm 0.13 ; t=2.99, P=0.0028)$, while Nosema loads did not differ by income streams.

\subsection{Viral prevalence by year}

Over the entire survey period, we analyzed viral prevalence of eight different honey bee viruses (see Tables I and IV). Mean ABPV prevalence varied by year $\left(\chi_{5}^{2}=23.38, n=2698\right.$, $P=0.0003$, see Figure 5a). Peaks of varying intensity consistently occurred during the winter months. The highest prevalence $(29.4 \%$ positive $)$ occurred in our first year of sampling in 2009, when bees from only CA and HI were analyzed. This dropped to $11.8 \%$ positive when sampling was increased to include 13 states in 2010. It continued to climb in 2011 (15.8\%) and 2012 $(22.9 \%)$ and has remained steady, near $20 \%$ prevalence, since then (Table IV).

BQCV was only tested from 2011 to 13; mean prevalence varied by year (Table IV, $\left.\chi_{2}^{2}=182.80, n=1360, P<0.0001\right)$. Initially $60.1 \%$ of samples tested positive in 2011 , but this climbed to $92.0 \%$ in 2012 and remained at $90.0 \%$ in 2013. Because of the high rate of prevalence, BQCV was replaced with LSV-2 for survey efforts E and F, samples collected in 2013 and 2014.

Mean CBPV prevalence varied by year (Table IV, $\chi_{5}^{2}=122.09, n=2698, P<0.0001$, see Figure $5 b$ ) and has increased steadily since it was first detected in 2010 in $0.7 \%$ of samples, doubling in prevalence annually.

Mean DWV prevalence varied by year (Table IV, $\chi_{5}^{2}=55.01, n=2698, P<0.0001$, see Figure $5 \mathrm{c}$ ). This virus showed annual peaks in late summer or fall, with troughs in January through March or

Table V. Migratory vs. stationary operations by year.

\begin{tabular}{lllllll}
\hline Year & Survey efforts & Respondents & Migratory & \% Migratory (\%) & Stationary & \% Stationary (\%) \\
\hline 2009 & A & 8 & 8 & 100.0 & 0 & 0.0 \\
2010 & A, B & 117 & 72 & 61.5 & 45 & 38.5 \\
2011 & B, C & 367 & 112 & 30.5 & 255 & 69.5 \\
2012 & C, D & 314 & 120 & 38.2 & 194 & 61.8 \\
2013 & D, E & 338 & 122 & 36.1 & 216 & 63.9 \\
2014 & E, F & 150 & 52 & 34.7 & 98 & 65.3 \\
Total & & 1294 & 486 & 37.6 & 808 & 62.4 \\
\hline
\end{tabular}

One thousand two hundred ninety-four respondents $(53.4 \%)$ were defined as migratory or stationary at the time of sampling out of 2423 sampled apiaries 
Table VI. Varroa and Nosema in migratory vs. stationary operations.

\begin{tabular}{lllll}
\hline & Migratory & Stationary & Test & $P$ value \\
\hline Samples & 484 & 807 & & \\
Varroa prevalence & $84.9 \%$ & $97.0 \%$ & $\chi^{2}=62.1$ & $<0.0001$ \\
CI & $81.4-87.8 \%$ & $95.6-97.9 \%$ & & \\
Varroa load, all samples & $3.65 \pm 0.28$ & $5.99 \pm 0.22$ & $t=6.54$ & $<0.0001$ \\
Varroa load, positive samples & $4.30 \pm 0.31$ & $6.17 \pm 0.23$ & $t=4.86$ & $<0.0001$ \\
Nosema prevalence & $59.9 \%$ & $46.7 \%$ & $\chi^{2}=21.22$ & $<0.0001$ \\
CI & $55.4-64.1 \%$ & $49.8-56.7 \%$ & & \\
Nosema load, all samples & $0.44 \pm 0.036$ & $0.24 \pm 0.027$ & $t=4.43$ & $<0.0001$ \\
Nosema load, positive samples & $0.74 \pm 0.058$ & $0.52 \pm 0.051$ & $t=2.81$ & $=0.0051$ \\
\hline
\end{tabular}

April. In 2009, $64.7 \%$ of all tested bees were DWV positive. In all subsequent years, prevalence was above $80 \%$ with a peak in 2012 of $92.1 \%$.

Mean IAPV prevalence varied by year (Table IV, $\chi^{2}{ }_{5}=102.09, n=2698, P<0.0001$, see Figure $5 \mathrm{~d}$ ), with an incidence rate of $11.8 \%$ in 2009 that dropped steadily through 2012, reaching a low of $4.1 \%$. It then surged up in 2013 to $15.94 \%$ and climbed to $19.46 \%$ in 2014. Prevalence showed annual peaks in February-April during the first 2 years, with peaks shifted to June-July in 2013 and 2014.

Mean KBV prevalence varied by year (Table IV, $\chi^{2}{ }_{5}=48.48, n=2698, P<0.0001$, see Figure 5e), with the highest levels detected in our limited first year of sampling in 2009. When the survey was expanded to 13 states, the prevalence dropped to $6.45 \%$. It stayed near this rate through 2012 and then jumped to $13.01 \%$ in 2013.

SBPV was never detected throughout the survey years, confirming its absence from the USA and territories. We adjusted our viral screens, adding LSV-2 with survey effort $\mathrm{E}$ in 2013. Mean LSV-2 prevalence varied across the 2 years of sampling (Table IV, $\chi^{2}{ }_{1}=19.08, n=2698$, $P<0.0001$, see Figure 6), jumping from $20.63 \%$ in 2013 to $33.40 \%$ in 2014 .

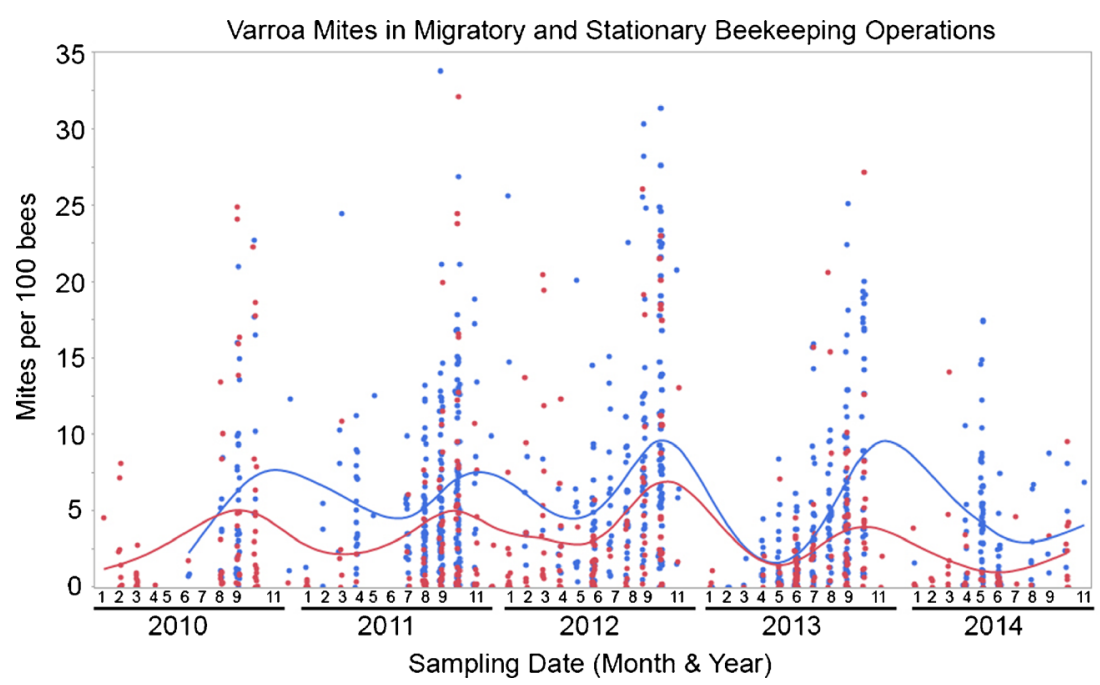

Figure 3. Mites per 100 bees, graphed for January, 2010 through November, 2014, segregated for migratory operations (red ) and stationary operations (blue). The $y$-axis was limited to 35 mites, so a few outliers are cutoff. 


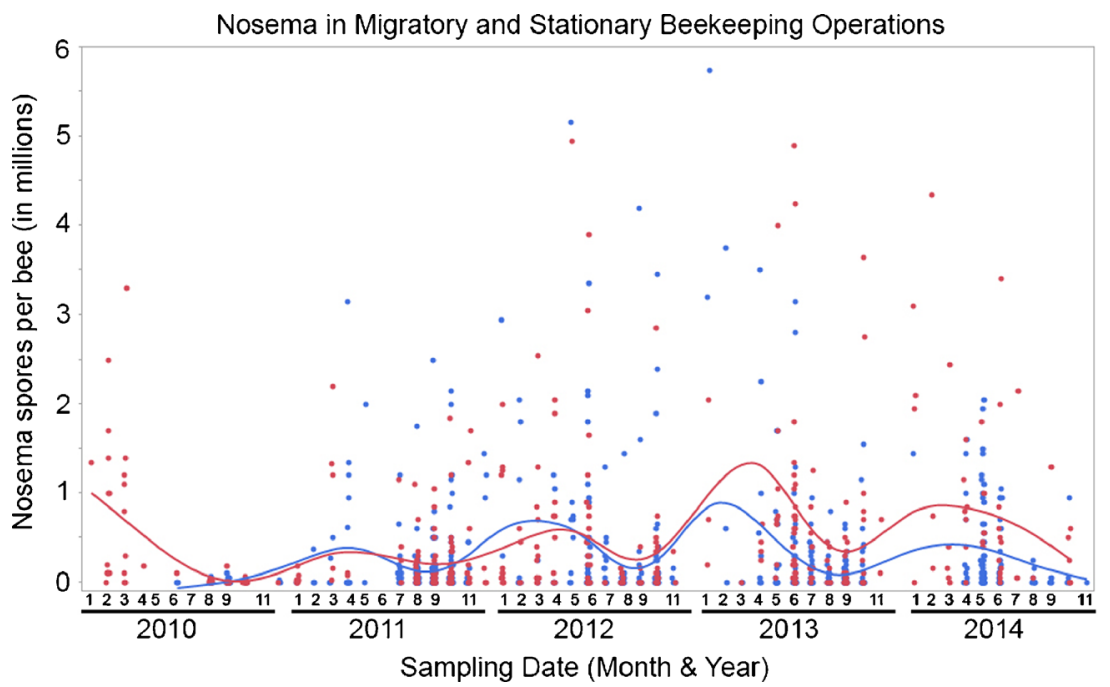

Figure 4. Nosema spores per bee, graphed for January, 2010 through November, 2014, segregated for migratory operations (red) and stationary operations (blue). The $y$-axis was limited to 6 million spores, so a few outliers are cutoff.

\subsection{Interactions between factors}

For interactions between factors, we excluded our initial sampling year of 2009, as there were only 17 samples analyzed from CA and HI, thus not representative of a nationwide survey as in later years. All results presented in this section examine trends over 5 years from 2010 to 2014.

Across all years, samples that tested positive for ABPV had more Varroa than samples that tested negative $\left(F_{1,2549}=31.63, P<0.001\right)$.

Table VII. Respondent operation type.

\begin{tabular}{lllll}
\hline Honey & Queen & Nuc & Pollination & Hobby \\
\hline 953 & 331 & 49 & 1574 & 9 \\
& Operational income streams & \\
Respondents & One & Two & Three & Total \\
Actual & 1826 & 494 & 34 & 2354 \\
Appear As & 1826 & 988 & 102 & 2916 \\
\hline
\end{tabular}

Beekeepers can select more than one income stream. Actual presents the actual number of beekeepers selecting one, two, or three different income streams. Since they are counted in each category, they appear as multiple respondents in each category; thus, when the different income streams are added up, the 2354 actual respondents appear as 2916 respondents
Varroa loads were significantly higher in ABPV-positive samples compared to negative samples in 2012 and 2014, though the trend was the same across all years except 2011 . There was a significant interaction between ABPV status and year (see Figure 7). We detected no relationship between ABPV and Nosema loads.

BQCV was only tested in 2011-2013. During these years, there was no significant difference in mite levels between BQCV-positive and BQCVnegative bees. However, BQCV-positive bees had higher Nosema levels than bees that tested negative across all 3 years $\left(F_{1,1335}=4.62, P=0.032\right)$. The Nosema infection level also varied by year $\left(F_{2,1335}=4.42, P=0.012\right)$, but there was no interaction of these two factors $\left(F_{2,1335}=0.73\right.$, $P=0.483$ ).

Across all years, Varroa loads were higher in bee samples that tested positive for DWV than those that tested negative (Figure 8, $\left.F_{1,2549}=61.02, P<0.001\right)$. Each year since 2011 , bees that tested positive for DWV had more mites than those that tested negative. Sampling year and DWV status interacted, though a similar trend of higher mite levels in DWV-positive compared to DWV-negative bees was seen in the last 4 years. In DWV-positive bees, there is a trend toward lower mite levels in the previous 2 years; 
Viral Prevalence of Honey Bee Viruses
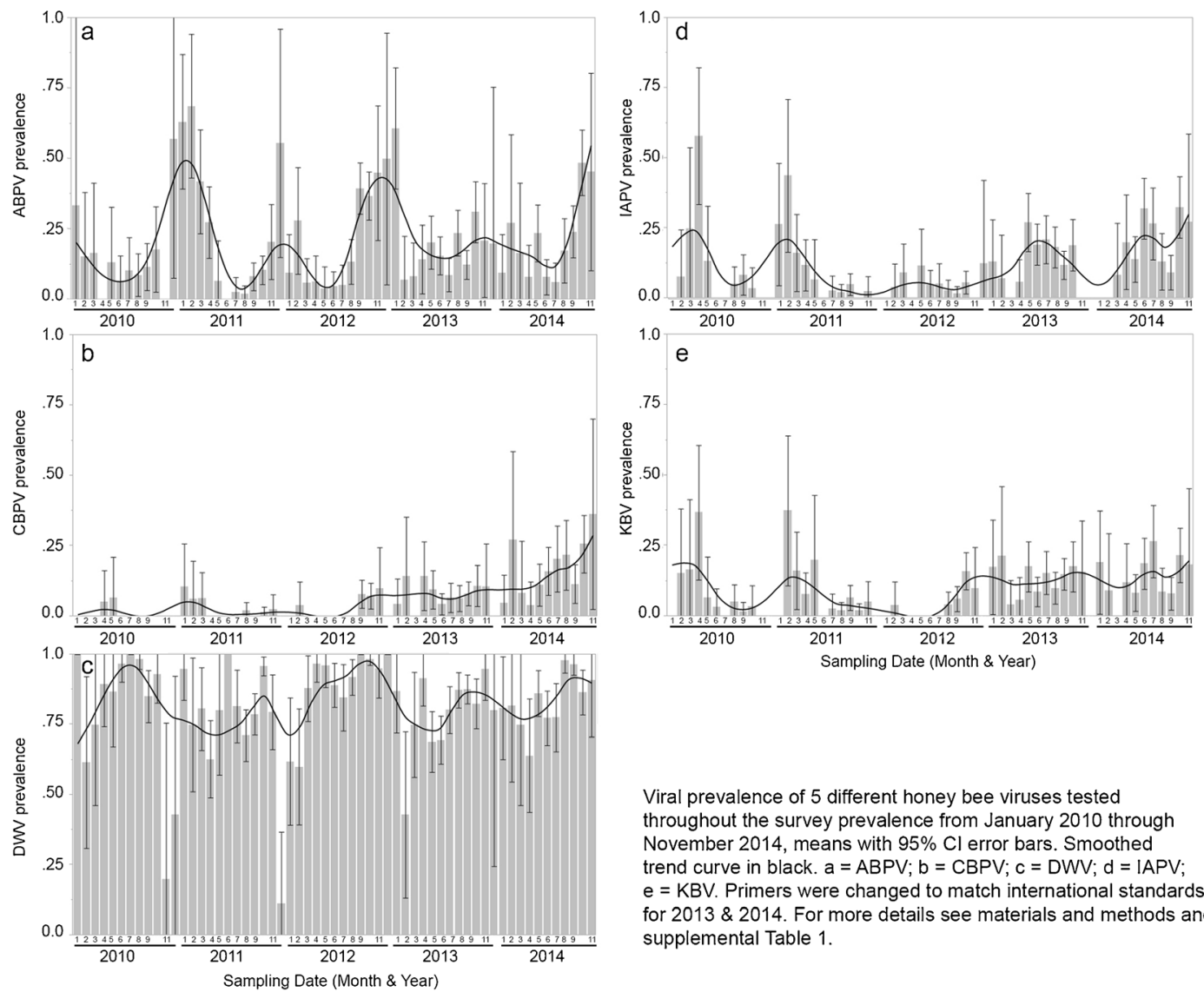

Viral prevalence of 5 different honey bee viruses tested throughout the survey prevalence from January 2010 through November 2014 , means with $95 \% \mathrm{Cl}$ error bars. Smoothed trend curve in black. $a=A B P V ; b=C B P V ; c=D W V ; d=I A P V ;$ $\mathrm{e}=\mathrm{KBV}$. Primers were changed to match international standards for 2013 \& 2014. For more details see materials and methods and supplemental Table 1.

Figure 5. Viral prevalence from January 2010 through November 2014, means with $95 \%$ CI error bars. Smoothed trend curve in black.

in 2011 and 2012, positive samples had 5.63 \pm 0.29 and $6.48 \pm 0.28$ mites, respectively, significantly higher than in 2013 when positive samples had only $4.30 \pm 0.21$ mites per 100 bees. In 2014, mite levels in DWV-positive bees fell again to a low $3.84 \pm 0.26$ mites although this drop did not differ significantly from the previous year. DWVpositive bees had mean Nosema spore loads of $0.35 \pm 0.019$ million spores per bee, lower than the $0.57 \pm 0.061$ mean of DWV-negative bees (Figure 9, $F_{1,2549}=11.58, P<0.001$ ).

For 2013 and 2014, when viral load was determined, there was a significant relationship between DWV viral abundance and Nosema spore load (Figure 10, $F_{2,814}=5.29, P=0.0052$ ). Bees negative for Nosema had significantly higher
DWV titers (log-transformed viral copies) than bees positive for Nosema spores. A Pearson product-moment correlation coefficient demonstrated a negative correlation between Nosema spore loads per bee and the log-transformed DWV viral copies $(r=-0.121, n=817$, $P<0.001)$.

In order to determine if comorbidity of two different virus infections occurred at rates higher than what would be expected, we calculated odds ratios (Batstra et al. 2002) and report significant relationships and relationships tending toward significance (chi-square test with $P<0.1$ ) in Table VIII. All detected viruses had seemingly synergistic and/or antagonistic associations (see vanEngelsdorp et al. 2013 for details on 
LSV-2 Prevalence

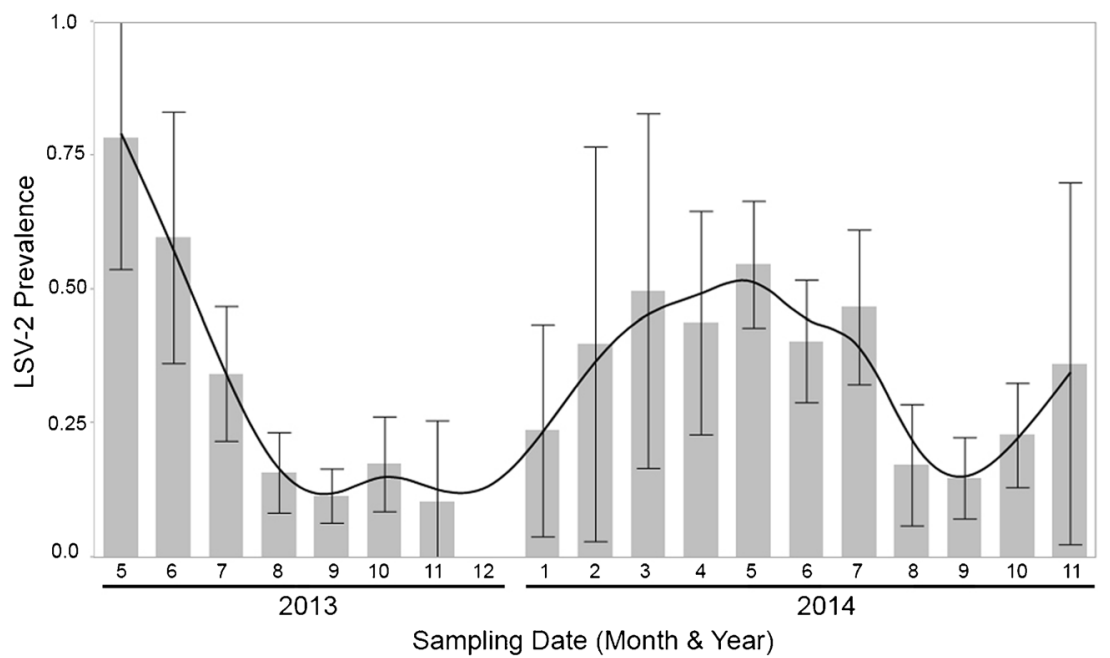

Figure 6. LSV prevalence from May 2013 through November 2014, mean plotted with $95 \%$ CI error bars . Smoothed trend curve in black.

odds ratio interpretation) with at least one other virus, while the presence of some viruses stood out for their apparent synergism, as their presence was strongly associated with the presence of other viruses. Notably, CBPV consistently increased the likelihood that ABPV, IAPV, KBV, and LSV-2 would be found in a sample (OR of 1.58, 2.54, 2.63, and 1.90 respectively), and its presence increased the chances of finding BQCV by a substantial OR factor of 7.28 .

Starting with survey E and continuing in survey $\mathrm{F}$, in years 2013 and 2014, viral load was measured using quantitative RT-PCR. Mean viral titers for both ABPV and DWV increased with the level of mite infestation, while LSV-2 showed the inverse relationship (Figure 11), with viral titers highest in bees with the lowest mite infestation.

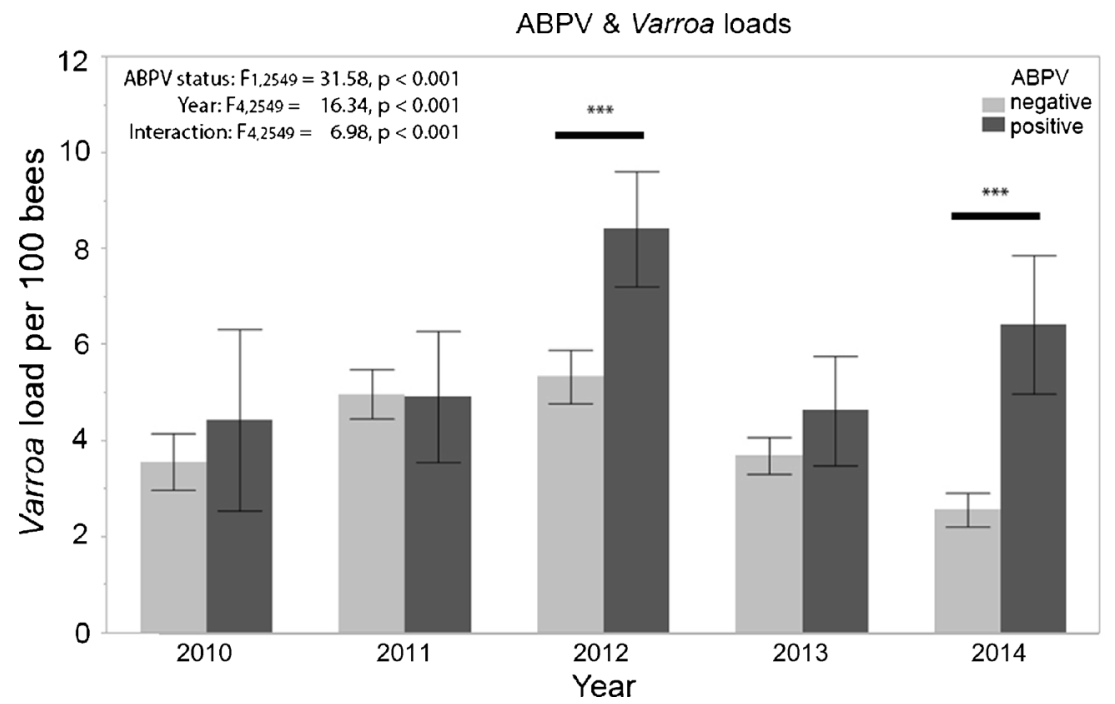

Figure 7. Varroa infestation levels in ABPV-positive (dark gray) and ABPV-negative (light gray) bees, $95 \%$ CI error bars. Significant differences indicated, ${ }^{* * *} P<0.0001$. 




Figure 8. Varroa infestation levels in DWV-positive (dark gray) and DWV-negative (light gray) bees, $95 \%$ CI error bars. Significant differences $(\alpha=0.05)$ indicated by different letters .

The more recently discovered LSV-2, added into the viral screen in 2013, was significantly correlated with Nosema spore counts (Figure 12). Bees free of Nosema had the lowest LSV-2 prevalence and load, while bees with spore counts above the treatment threshold of 1 million spores per bee were $2.5 \times$ more likely to be LSV-2 positive.

Since the number of viruses screened varied between survey years, we calculated the positive viral infection rate (no. of positive viral tests/ no. of viruses tested) to compare virus infection rates across years. It varied significantly by year from a low of $16.6 \%$ in 2010 to a high of $31.5 \%$ in 2012. Viral infection rate peaked in 2012 , the same year that samples experienced elevated Varroa infestation levels (Figure 13). Viral infection rate and mite load followed the same pattern from year to year; mites per 100 bees and virus infection were correlated across all samples, Pearson $r=0.14, n=2576$, $P<0.0001$. When samples from 2012 are analyzed separately, the correlation doubled, Pearson $r=0.28, n=581, P<0.0001$.

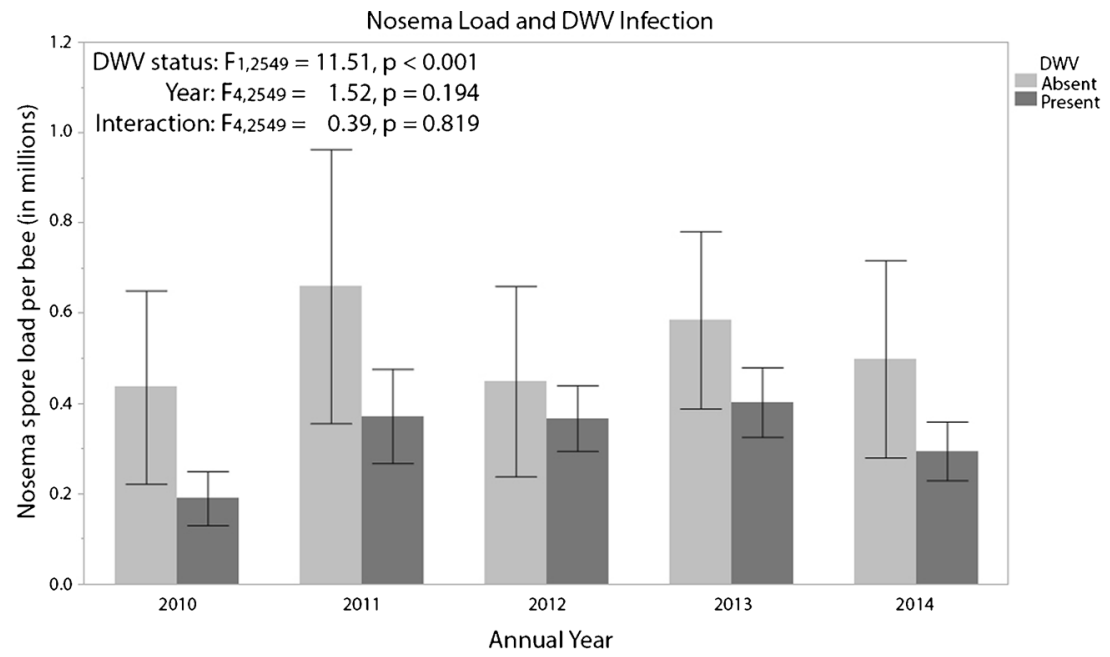

Figure 9. Nosema loads in DWV-positive (dark gray) and DWV-negative (light gray) bees, annual means depicted with $95 \%$ CI error bars . 


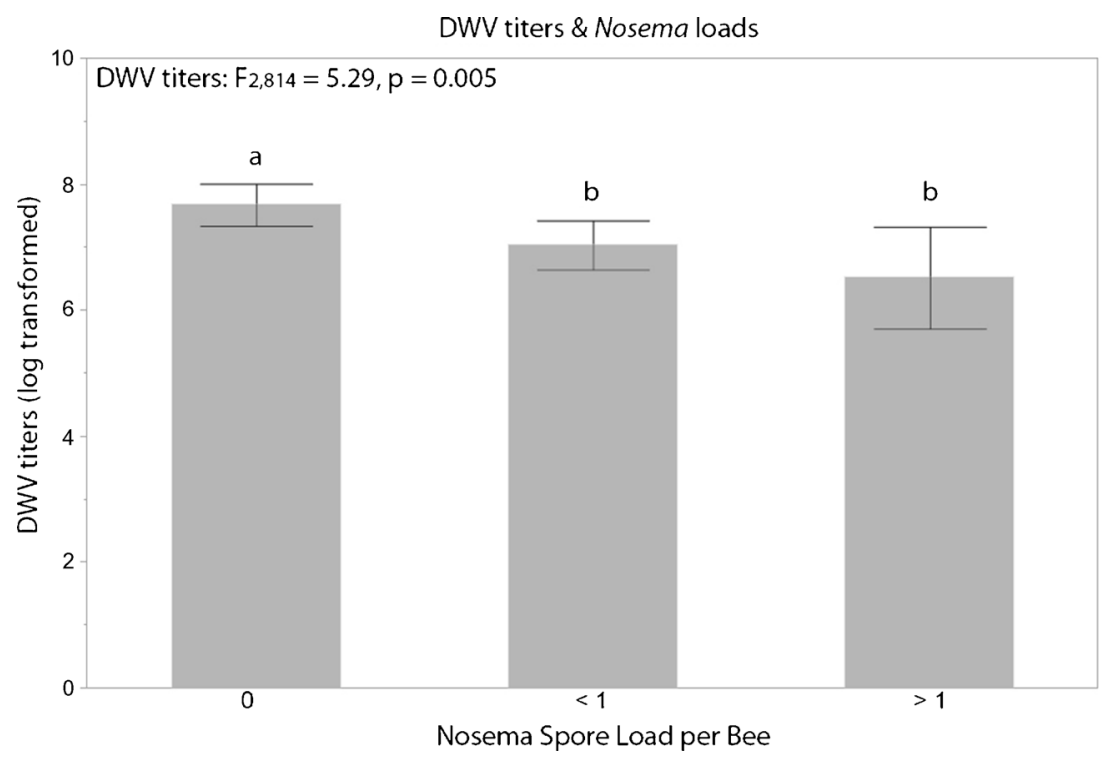

Figure 10. Mean DWV titers (log transformed) with $95 \%$ CI error bars. Bees negative for Nosema have significantly higher DWV titers than bees positive for Nosema .

\section{DISCUSSION}

Longitudinal monitoring of honey bee colonies from 2009 to 2014 confirms the absence of three critical threats to honey bee health in the USA and territories: (1) the rapidly reproducing Tropilaelaps mite; (2) the Asiatic honey bee, A. cerana, an invasive pest bee species in Australia and the Solomon Islands and a vector of honey bee disease and parasites; and (3) the virus SBPV, the only virus tested that is not currently found in the USA. In addition, the NHBDS allowed for the establishment of a baseline of honey bee diseases, the annual cycles of honey bee parasites, and the pervasiveness of honey bee viruses in the USA.

Throughout the duration of the NHBDS, 41 states and two territories participated, sending honey bee samples for $V$. destructor, Nosema spp., and viral analysis. Participation rates remained high throughout the duration of the survey, though successful respondent rate fell somewhat in the survey year when apiary inspectors who collected the samples were no longer reimbursed for their time (Table II). Often, the return rate increases during the following beekeeping season, when inspectors mail back survey kits that they retained from the prior year.
The mean mite load per 100 bees varied significantly from year to year from a low of $3.3 \pm 0.3$ in 2014 to a high of $5.8 \pm 0.2$ in 2012 , but across all years, the annual cyclical trend was consistent. Varroa infestations were consistently low from January through June, with mean infestations remaining below the recommended treatment threshold of three mites/100 bees (Genersch et al. 2010; Giacobino et al. 2015). Annual peaks occurred from August through November, when mean mite levels regularly exceeded the treatment threshold. In the first 3 months of the year, $75 \%$ of all samples were below the three-mite treatment threshold. During the months of September through November, we consistently find samples with $25+$ mites. Such high mite levels suggest that healthy colonies may be picking up additional mites from colonies collapsing within the apiary's vicinity. National winter loss surveys indicate that $60 \%$ of hobby beekeepers do not treat for Varroa (Steinhauer et al. 2014). Without beekeeper Varroa management interventions, these colonies almost inevitably crash (Francis et al. 2013), releasing abundant mites that invade healthy colonies by switching from nurse bees to foragers (Cervo et al. 2014) and swapping hosts via communal foraging or robbing (Frey et al. 2011). Mite levels peak during the critical time of year, when 
Table VIII. Odds ratios.

\begin{tabular}{lll}
\hline Response & Factor & \multicolumn{1}{c}{ OR $(95 \% \mathrm{CI})$} \\
\hline Varroa & DWV & $4.47(3.38-5.93)$ \\
Nosema & LSV-2 & $0.45(0.28-0.75)$ \\
& DWV & $0.67(0.55-0.83)$ \\
& IAPV & $1.41(1.10-1.81)$ \\
ABPV & LSV-2 & $2.43(1.76-3.36)$ \\
& BQCV & $11.27(5.51-23.06)$ \\
& CBPV & $1.58(1.07-2.33)$ \\
& DWV & $2.18(1.59-2.99)$ \\
BQCV & IAPV & $1.66(1.24-2.21)$ \\
& KBV & $1.82(1.35-2.46)$ \\
& CBPV & $7.28(1.76-30.15)$ \\
& DWV & $3.62(2.74-4.78)$ \\
CBPV & IAPV & $6.73(2.45-18.51)$ \\
& KBV & $4.60(1.84-11.48)$ \\
& IAPV & $2.54(1.68-3.83)$ \\
DWV & KBV & $2.63(1.71-4.04)$ \\
IAPV & LSV-2 & $1.90(1.22-2.99)$ \\
& KBV & $1.55(1.05-2.29)$ \\
& KBV & $12.86(9.58-17.27)$ \\
& LSV-2 & $1.73(1.18-2.53)$ \\
\hline
\end{tabular}

Odds ratio analysis for Varroa, Nosema, and viral prevalence.Confidence intervals greater than one suggest an increased likelihood of co-infection. Confidence intervals that are below one, suggest an inhibitory relationship. Since odds ratio results are identical, regardless which variable is considered the response, we did not duplicate results in the table, i.e. $\mathrm{ABPV} \& \mathrm{BQCV}$ is reported under $\mathrm{ABPV}$ and not repeated under BCQV.

$A B P V$ acute bee paralysis virus; $B Q C V$ black queen cell virus; $C B P V$ chronic bee paralysis virus; $D W V$ deformed wing virus; $I A P V$ Israeli acute paralysis virus; $K B V$ Kashmir bee virus; $L S V$ - 2 Lake Sinai Virus-2; $C I$ confidence intervals.

in temperate climates, colonies must rear their winter bees to survive the coming nectar dearth and long period of confinement. From September through November, only $30-45 \%$ of samples tested were below the three-mite threshold. Thus, more than half of all beekeepers surveyed entered the winter with elevated mite infestations, which have been shown to contribute significantly to winter colony mortality (Becher et al. 2013; Carreck et al. 2010; Francis et al. 2013; Le Conte et al. 2010; vanEngelsdorp et al. 2012).
Nosema spore counts were more consistent than mean Varroa infestations across survey years, with mean spore counts dependably below 0.5 million spores per bee, far below the treatment threshold of 1 million spores per bee. Only 2010 had significantly lower spore counts compared to later years (Table III), perhaps due to below-normal cold winter conditions experienced in the south, southeast, and central USA during January and February (http://www.erh.noaa.gov/rnk/Newsletter/ Spring_2010/winter_climate_summary.html) since $N$. ceranae is sensitive to low temperatures (Forsgren and Fries 2013). The only month when mean spore counts exceeded 1 million spores is April, when colonies are often nutritionally stressed coming out of winter and may be confined due to spring rains. $N$. apis is exceedingly rare, appearing in less than $2 \%$ of samples in 2012 and 2013, while $N$. ceranae steadily increased in prevalence, detected in just under one third of all samples in 2009 to a high of almost $90 \%$ prevalence in 2013, the last year where we monitored for Nosema species.

Interestingly, stationary and migratory beekeepers varied significantly in their Nosema and Varroa levels. Stationary beekeepers tended to have higher mite infestations and lower Nosema spore loads, while migratory beekeepers showed the opposite trend. Migratory beekeepers may be treating more frequently to reduce Varroa populations, or the physical movement of trucking bees for pollination may be interfering with mite reproduction.

Varroa levels were significantly elevated in bees positive for both ABPV (Figure 7) and DWV (Figure 8), highlighting the role of Varroa as viral vectors (Ball and Allen 1988; Bowen-Walker et al. 1999; Mondet et al. 2014). ABPV has long been associated with increased honey bee mortality in mite-infested colonies (Ball and Allen 1988). The ABPV virus replicates in adult bees and larvae, leading to increased mortality in the presence of mites (Brødsgaard et al. 2000). Unfortunately, due to the difficulty and cost of tracking large numbers of colonies over time, the survey provides a snapshot of disease loads in surveyed apiaries at single time points and thus cannot address what disease states are linked with increased colony mortality.

As in previous studies, increased mite levels were associated with increased prevalence of DWV (Ball and Allen 1988; Bowen-Walker et al. 
The Impact of Varroa Mite Infestation on Mean Viral Titers

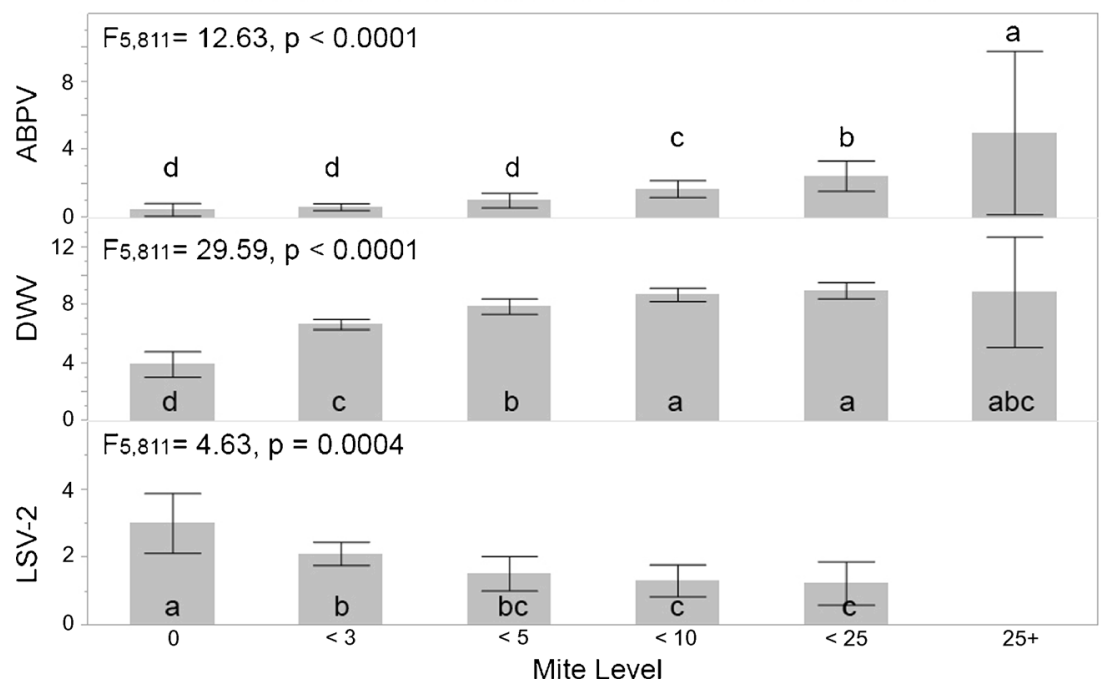

Figure 11. Mean viral titers (log transformed) with $95 \%$ CI error bars for different mite infestation levels for ABPV (top ), DWV (center), and LSV-2 (bottom). Significant differences $(\alpha=0.05)$ indicated by different letters .

1999; Gisder et al. 2009). DWV prevalence increased from a low of $64.71 \%$ in 2009 when only 17 samples were processed from CA and HI to a high of $92.14 \%$ in 2012, the same year that also had the highest mean mite levels (Table IV). Although mean mite levels fell off after the high of 2012, DWV prevalence remained above $80 \%$. Thus, bees were DWV positive in 2013 and 2014 despite having lower mean mite levels, significantly lower Varroa infestation levels than DWV-positive bees in 2012 (Figure 8). This suggests that longterm exposure to Varroa leads to persisting

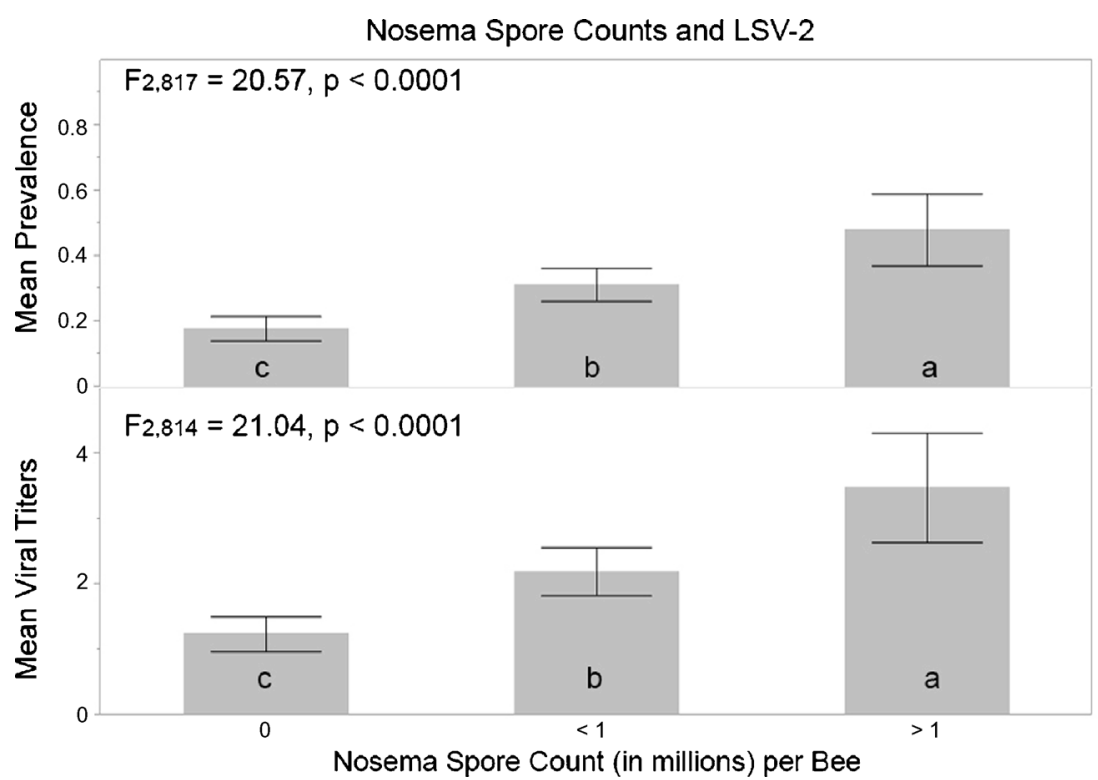

Figure 12. Mean LSV-2 prevalence (top) and viral titers (log transformed on bottom) with $95 \%$ CI error bars for different Nosema infestation levels. Significant differences $(\alpha=0.05)$ indicated by different letters . 


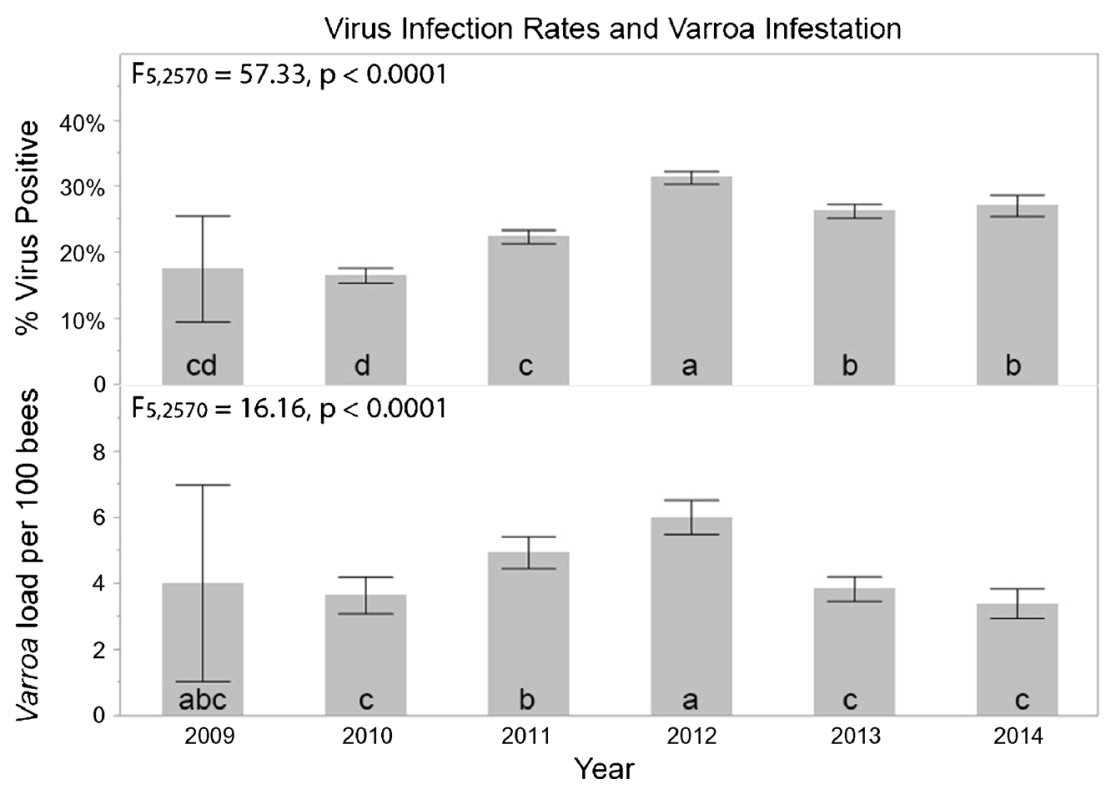

Figure 13. Rate of positive viral infection, calculated as the no. of positives/no. of viruses tested (top) and Varroa load per 100 bees (bottom), plotted by annual year with $95 \%$ CI error bars. Significant differences $(\alpha=0.05)$ indicated by different letters .

elevated DWV titers despite a temporary decrease in mite loads. The shift toward greater viral prevalence at lower Varroa infestation rates may also be influenced by a change in RNA extraction and amplification methods (see Table S1), protocol changes made to meet international guidelines, so that results are comparable across studies.

In 2013 and 2014, we measured viral titers across Varroa infestation levels. Both ABPV and DWV varied significantly across mite infestation levels, increasing in viral load linearly with mite levels. Mite presence appears to be directly linked to virus replication for these two viruses. Interestingly, LSV2 showed the opposite pattern, with viral load greatest in mite-free samples and dropping significantly as mite infestation levels increased (Figure 11). However, LSV-2 viral prevalence and load correlated with Nosema spore counts (Figure 12), indicating a close relationship. As Varroa infestation levels and Nosema spore counts peak at opposite times of the year, it is not surprising that LSV-2 correlates positively with Nosema and negatively with mites. This correlation might reflect seasonal life histories of parasites and pathogens. Alternatively, there might be a complex double-repressor relationship between ABPV/DWV/Varroa and LSV-2/ Nosema. The three viruses may be competing to use the same machinery to replicate, with ABPV and DWV outcompeting LSV-2. A third possibility is that LSV-2 is directly linked with Nosema, which in turn inhibits DWV replication. Prior establishment in the host ventriculus by Nosema has been shown to inhibit DWV establishment (Doublet et al. 2015). Their results demonstrated that prior infection by DWV did not impact $N$. ceranae, while our survey results suggest that DWV load may negatively impact the establishment of Nosema, as bees free of Nosema had significantly higher DWV load than bees infected with Nosema (Figure 10).

The viral screens conducted suggest an escalation in prevalence of several viruses over the last 5 years (Table IV). BQCV, CBPV, KBV, and LSV-2 all increased in prevalence as $\operatorname{did} N$. ceranae. Undetected in 2009, the prevalence of CBPV has doubled annually, a worrisome trend in light of all the other stressors impacting honey bee health. An increasing trend in multiple viruses and parasites may suggest a compromised honey bee immune system, unable to protect itself well against a wide multitude of stressors such as a 
fragmented agricultural landscape, increased pressure from pesticides, and poor nutrition (Archer et al. 2014; Bryden et al. 2013; Higes et al. 2009; Pettis et al. 2013a; Sanchez-Bayo and Goka 2014; Simon-Delso et al. 2014; van der Sluijs et al. 2013), leading to increased colony mortality (Johnson et al. 2010; Spleen et al. 2013; Steinhauer et al. 2014; vanEngelsdorp et al. 2012; vanEngelsdorp et al. 2008). Our results also quantify the relationships between Varroa infestation and levels of a diverse set of viruses, suggesting a complex, interactive relationship.

Longitudinal surveys offer a rare look at seasonal and yearly patterns for agents that threaten honey bee health. Results from such surveys can help identify the causes of poor honey bee health, provide warning signs of emergent threats, and can direct mitigation efforts for these threats. The NHBDS establishes the essential baseline of viral and parasite prevalence, building a strong foundation to monitor change and predict future issues of honey bee health. Varroa plays an integral part in virus infection rates, and beekeeper intervention to control escalating infestations must continue to be a priority. The annual doubling of CBPV prevalence, recognized as part of a new group of positive-strand RNA viruses and a risk factor for colony weakness (Ribiere et al. 2010), indicates that colony health may continue to decline unless steps are taken to alleviate the multiple stressors plaguing colony health. Having laid a strong foundation for epidemiological studies, we should continue to monitor viral and parasite loads and tie in longitudinal studies where possible, to determine their impacts on colony health.

\section{ACKNOWLEDGMENTS}

We would like to thank USDA APHIS for assistance with coordination and funding of the survey and Apiary Inspectors of America for collecting the samples in the field. We would also like to thank the following for support in sample collection, kit construction, sample processing, and analysis: Sam Abban, Michael Andree, Tyler Conine, Heather Eversole, Rachel Fahey, Andrew Garavito, Ashley Jones, Vic Levi, Meghan McConnell, Anthony Nearman, Nishit Patel, Nathan Rice, Karen Roccasecca, Bart Smith Jr., Margaret Smith, Steven Smith, Robert Snyder, Nathalie Steinhauer, and Jennie Stitzinger.

\section{OPEN ACCESS}

This article is distributed under the terms of the Creative Commons Attribution 4.0 International License (http://creativecommons.org/licenses/by/4.0/), which permits unrestricted use, distribution, and reproduction in any medium, provided you give appropriate credit to the original author(s) and the source, provide a link to the Creative Commons license, and indicate if changes were made.

Etude pluriannuelle visant à définir I'incidence des maladies sur les abeilles aux Etats -Unis

Apis mellifera / surveillance sanitaire / ravageur/ parasite / apiculteurs américains

Mehrjährige Übersichtsuntersuchung zu Krankheitsursachen bei Honigbienen in den Vereinigten Staaten

Apis mellifera / Krankheitsuntersuchung / Schädlinge / Parasiten / USA

\section{REFERENCES}

Archer, C.R., Pirk, C.W.W., Wright, G.A., Nicolson, S.W. (2014) Nutrition affects survival in African honeybees exposed to interacting stressors. Funct. Ecol. 28, 913-923

Bailey L., Ball B.V. (1991) Honey bee pathology. Academic Press

Ball, B.V., Allen, M.F. (1988) The prevalence of pathogens in honey bee (Apis mellifera) colonies infested with the parasitic mite Varroa jacobsoni. Ann. Appl. Biol. 113, 237-244

Batstra, L., Bos, E.H., Neeleman, J. (2002) Quantifying psychiatric comorbidity-lessions from chronic disease epidemiology. Soc. Psychiatry Psychiatr. Epidemiol. 37, 105-111

Becher, M.A., Osborne, J.L., Thorbek, P., Kennedy, P.J., Grimm, V. (2013) REVIEW: Towards a systems approach for understanding honeybee decline: a stocktaking and synthesis of existing models. J. Appl. Ecol. 50, $868-880$

Bowen-Walker, P.L., Martin, S.J., Gunn, A. (1999) The transmission of deformed wing virus between honeybees (Apis mellifera L.) by the ectoparasitic mite Varroa jacobsoni Oud. J. Invertebr. Pathol. 73, 101-106

Brødsgaard, C.J., Ritter, W., Hansen, H., Brødsgaard, H.F. (2000) Interactions among Varroa jacobsoni mites, acute paralysis virus, and Paenibacillus larvae larvae and their influence on mortality of larval honeybees in vitro. Apidologie 31, 543-554 
Bryden, J., Gill, R.J., Mitton, R.A.A., Raine, N.E., Jansen, V.A.A. (2013) Chronic sublethal stress causes bee colony failure. Ecol. Lett. 16, 1463-1469

Bustin, S.A., Benes, V., Garson, J.A., Hellemans, J., Huggett, J., et al. (2009) The MIQE guidelines: minimum information for publication of quantitative real-time PCR experiments. Clin. Chem. 55, 611-622

Calderone, N.W. (2012) Insect Pollinated Crops, Insect Pollinators and US Agriculture: Trend Analysis of Aggregate Data for the Period 1992-2009. PLoS ONE 7, e37235. doi:10.1371/ journal.pone.0037235

Cantwell, G.E. (1970) Standard methods for counting Nosema spores. Am. Bee J. 110, 222-223

Carreck, N.L., Bell, B.V., Martin, S.J. (2010) Honey bee colony collapse and changes in viral prevalence associated with Varroa destructor . J. Apic. Res. 49, 93-94

Cervo, R., Bruschini, C., Cappa, F., Meconcelli, S., Pieraccini, G., Pradella, D., Turillazzi, S. (2014) High Varroa mite abundance influences chemical profiles of worker bees and mite-host preferences. J. Exp. Biol. 217, 2998-3001

de Miranda J.R., Bailey L., Ball B.V., Blanchard P., Budge G.E., et al. (2013) Standard methods for virus research in Apis mellifera. In: Dietemann V, Ellis JD, Neumann P (eds) The COLOSS BEEBOOK, Volume II: standard methods for Apis mellifera pest and pathogen research. J. Apic. Res. vol 52 (4) doi:10.3896/ibra.1.52.4.22

DeGrandi-Hoffman, G., Chen, Y.P., Huang, E., Huang, M.H. (2010) The effect of diet on protein concentration, hypopharyngeal gland development and virus load in worker honey bees (Apis mellifera L.) J. Insect Physiol. 56, 1184-1191

DeJong, D., Roma, D.D., Goncalves, L.S. (1982) A comparative analysis of shaking solutions for the detection of Varroa jacobsoni on adult honeybees. Apidologie 13, 297-306

Di Prisco, G., Cavaliere, V., Annoscia, D., Varricchio, P., Caprio, E., et al. (2013) Neonicotinoid clothianidin adversely affects insect immunity and promotes replication of a viral pathogen in honey bees. Proc. Natl Acad. Sci. USA 110, 18466-18471

Di Prisco, G., Zhang, X., Pennachio, F., Caprio, E., Li, J.L., et al. (2011) Dynamics of Persistent and Acute Deformed Wing Virus Infections in Honey Bees, Apis mellifera. Viruses-Basel 3, 2425-2441

Doublet, V., Natsopoulou, M.E., Zschiesche, L., Paxton, R.J. (2015) Within-host competition among the honey bees pathogens Nosema ceranae and Deformed wing virus is asymmetric and to the disadvantage of the virus. J. Invertebr. Pathol. 124, 31-34

Evans, J.D. (2006) Beepath: an ordered quantitative-PCR array for exploring honey bee immunity and disease. J. Invertebr. Pathol. 93, 135-139

Evans, J.D., Schwarz, R.S., Chen, Y.P., Budge, G., Cornman R.S., et al. (2013) Standard methods for molecular research in Apis mellifera. In: Dietemann $\mathrm{V}$, Ellis JD, Neumann P (eds) The COLOSS
BEEBOOK, Volume I: standard methods for Apis mellifera research. J. Apic. Res. 52(4) doi:10.3896/ ibra.1.52.4.11

Forsgren, E., Fries, I. (2013) Temporal study of Nosema spp. in a cold climate. Environ. Microbiol. Rep. 5, 78-82

Francis RM, Nielsen SL, Kryger P (2013) Varroa-Virus Interaction in Collapsing Honey Bee Colonies. PLoS ONE 8, doi:10.1371/journal.pone.0057540

Frey, E., Schnell, H., Rosenkranz, P. (2011) Invasion of Varroa destructor mites into mite-free honey bee colonies under the controlled conditions of a military training area. J. Apic. Res. 50, 138-144

Genersch E, Aubert M (2010) Emerging and re-emerging viruses of the honey bee (Apis mellifera L.). Vet. Res. 41, doi:10.1051/vetres/2010027

Genersch, E., von der Ohe, W., Kaatz, H., Schroeder, A., Otten, C., et al. (2010) The German bee monitoring project: a long term study to understand periodically high winter losses of honey bee colonies. Apidologie 41, 332-352

Giacobino, A., Molineri, A., Cagnolo, N.B., Merke, J., Orellano, E., et al. (2015) Risk factors associated with failures of Varroa treatments in honey bee colonies without broodless period. Apidologie 46(5), 573-582

Gisder, S., Aumeier, P., Genersch, E. (2009) Deformed wing virus: replication and viral load in mites (Varroa destructor ). J. Gen. Virol. 90, 463-467

Higes, M., Martin-Hernandez, R., Garrido-Bailo, E., GonzalesPorto, A.V., Garcia Palencia, P., et al. (2009) Honeybee colony collapse due to Nosema ceranae in professional apiaries. Environ. Microbiol. Rep. 1, 110-113

Johnson, R.M., Ellis, M.D., Mullin, C.A., Frazier, M. (2010) Pesticides and honey bee toxicity - USA. Apidologie 41, 312-331

Koepsell, T.D., Weiss, N.S. (2003) Epidemiologic methods: studying the occurrence of illness. Oxford University Press, Oxford; New York

Le Conte, Y., Ellis, M., Ritter, W. (2010) Varroa mites and honey bee health: can Varroa explain part of the colony losses? Apidologie 41, 353-363

Lee, K., Steinhauer, N., Rennich, K., Wilson, M.E., Tarpy, D.R., et al. (2015) A national survey of managed honey bee 2013-2014 annual colony losses in the USA. Apidologie 46 (3), 292-305

Lee, K.V., Moon, R.D., Burkness, E.C., Hutchison, W.D., Spivak, M. (2010) Practical Sampling Plans for Varroa destructor (Acari: Varroidae) in Apis mellifera (Hymenoptera: Apidae) Colonies and Apiaries. J. Econ. Entomol. 103, 1039-1050

Locke, B., Forsgren, E., de Miranda, J.R. (2014) Increased Tolerance and Resistance to Virus Infections: A Possible Factor in the Survival of Varroa destructor Resistant Honey Bees (Apis mellifera). PLoS ONE 9, e99998. doi:10.1371/journal.pone.0099998

Locke, B., Forsgren, E., Fries, I., de Miranda, J.R. (2012) Acaricide treatment affects viral dynamics in Varroa destructor -infested honey bee colonies via both host 
physiology and mite control. Appl. Environ. Microbiol. 78, 227-235

Mondet, F., de Miranda, J.R., Kretzschmar, A., Le Conte, Y., Mercer, A.R. (2014) On the Front Line: Quantitative Virus Dynamics in Honeybee (Apis mellifera L.) Colonies along a New Expansion Front of the Parasite Varroa destructor. PLoS Path 10, doi:10.1371/journal.ppat.1004323

Obama, B. (2014) Creating a Federal Strategy to Promote the Health of Honey Bees and Other Pollinators. Office of the Press Secretary, Washington, DC

OIE (2014) Terrestrial Code. 23rd edn

Pettis JS, Lichtenberg EM, Andree M, Stitzinger J, Rose R, vanEngelsdorp D (2013a) Crop Pollination Exposes Honey Bees to Pesticides Which Alters Their Susceptibility to the Gut Pathogen Nosema ceranae. PLoS ONE 8, doi:10.1371/journal.pone.0070182

Pettis, J.S., Rose, R., Lichtenberg, E.M., Chantawannakul, P., Buawangpong, N., et al. (2013b) A Rapid Survey Technique for Tropilaelaps Mite (Mesostigmata: Laelapidae) Detection. J. Econ. Entomol. 106, 1535-1544

Ribière, M., Ball, B.V., Aubert, M. (2008) Natural history and geographical distribution of honey bee viruses. In: Aubert, M. (ed.) Virology and the honey bee, pp. 1584. European Commissioner, Luxembourg

Ribiere, M., Olivier, V., Blanchard, P. (2010) Chronic bee paralysis: A disease and a virus like no other? J. Invertebr. Pathol. 103, S120-S131. doi:10.1016/ j.jip.2009.06.013

Rose, R., Pettis, J.S., Rennich, K., VanEngelsdorp, D. (2014) A US national survey of honey-bee pests and diseases. World Organization for Animal Health (OIE)

Runckel, C., Flenniken, M.L., Engel, J.C., Ruby, J.G., Ganem, D., Andino, R., DeRisi, J.L. (2011) Temporal Analysis of the Honey Bee Microbiome Reveals Four Novel Viruses and Seasonal Prevalence of Known Viruses, Nosema , and Crithidia . PloS ONE 6, e20656

Sanchez-Bayo, F., Goka, K. (2014) Pesticide Residues and Bees - A Risk Assessment. PLoS ONE 9, e94482. doi:10.1371/journal.pone.0094482

Shimanuki, H., Knox, D.A. (2000) Diagnosis of Honey Bee Diseases. US Department of Agriculture Agricultural Research Service, 1-57

Simon-Delso N, San Martin G, Bruneau E, Minsart L-A, Mouret C, Hautier L (2014) Honeybee Colony Disorder in Crop Areas: The Role of Pesticides and Viruses. PLoS ONE 9, doi:10.1371/journal.pone.0103073
Spleen AM., Lengerich E.J., Rennich K., Caron D., Rose R. et al. (2013) A national survey of managed honey bee 2011-12 winter colony losses in the United States: results from the Bee Informed Partnership. J. Apic. Res. 52, doi:10.3896/ ibra.1.52.2.07

Steinhauer, N.A., Rennich, K., Wilson, M.E., Caron, D.M., Lengerich, E.J., et al. (2014) A national survey of managed honey bee 2012-2013 annual colony losses in the USA: results from the Bee Informed Partnership. J. Apic. Res. 53 , 1-18. doi:10.3896/ibra.1.53.1.01

Tautz Jr. (2008) The buzz about bees: biology of a superorganism. Springer, Berlin

van der Sluijs, J.P., Simon-Delso, N., Goulson, D., Maxim, L., Bonmatin, J.-M., Belzunces, L.P. (2013) Neonicotinoids, bee disorders and the sustainability of pollinator services. Curr. Opin. Environ. Sustain. 5, 293-305

vanEngelsdorp, D., Caron, D., Hayes, J., Underwood, R., Henson, M., et al. (2012) A national survey of managed honey bee 2010-11 winter colony losses in the USA: results from the Bee Informed Partnership. J. Apic. Res. 51, 115-124

vanEngelsdorp, D., Cox-Foster, D., Frazier, M., Ostiguy, N., Hayes, J. (2007) "Fall-Dwindle Disease": Investigations into the causes of sudden and alarming colony losses experienced by beekeepers in the fall of 2006

vanEngelsdorp D., Evans J.D., Saegerman C., Mullin C., Haubruge E. et al. (2009) Colony Collapse Disorder: A descriptive study. PloS ONE 4, doi:10.1371/ journal.pone.0006481

vanEngelsdorp, D., Hayes Jr., J., Underwood, R.M., Pettis, J. (2008) A Survey of Honey Bee Colony Losses in the U.S., Fall 2007 to Spring 2008. PLoS ONE 3, e4071. doi:10.1371/journal.pone.0004071

vanEngelsdorp D., Lengerich E., Spleen A., Dainat B., Cresswell J. et al. (2013a) Standard epidemiological methods to understand and improve Apis mellifera health. J. Apic. Res. 52, doi:10.3896/ ibra.1.52.4.15

vanEngelsdorp, D., Saegerman, C., Nguyen, B.K., Pettis, J. (2014) Honey bee health surveillance. In: OIE

vanEngelsdorp, D., Tarpy, D.R., Lengerich, E.J., Pettis, J.S. (2013) Idiopathic brood disease syndrome and queen events as precursors of colony mortality in migratory beekeeping operations in the eastern United States. Prev. Vet. Med. 108, 225-233 